attorney; 2) conducting a search of the person opposite to the defense counsel; 3 ) extending the rights of a person who is not yet procedural in order to protect his rights and legitimate interests; 4 ) the regulation of the duty of the investigator to inform the defense counsel in advance of all subsequent procedural actions involving the suspect; 5) the determination of the time during which the defender must arrive at the place of the search; 6) fixing the voluntary refusal in the case of the participation of a defender during a search, 7) conducting a search on the initiative of the defense party. A number of proposals aimed at improving the current Criminal Procedural Code of Ukraine in the part of the procedural regulation of the activity of a lawyer-advocate on the provision of legal assistance to a person during a search are expressed. In particular, paragraphs 1 and 5 of Article 236 of the Criminal Procedural Code of Ukraine have been analyzed and it is proposed to add an addition to Part 5 of this Article of the Code. The content of the addendum is that the search of a person can be carried out not only in the presence of a lawyer or representative, but also a person's defense depending on the procedural status given to her.

The proposals are aimed at procedural settlement of the cases of the invitation of a lawyer or counsel to provide qualified legal assistance in order to protect the rights and lawful interests of the suspect and other persons who are being searched.

Key words: investigative (search) actions, search of a home or other person's possession, search of a person, defender, lawyer, suspect, other participant in criminal proceedings.

УДК 343.241

Epodeeb M.I.

кандидат юридичних наук, науковий співробітник науково-дослідної лабораторії з проблем попередження, припинення та розслідування злочинів територіальними органами Національної поліції України Луганського державного університету внутрішніх справ імені Е.О. Дідоренка (м. СєВєродонещьк, Україна)

\title{
ПРАВОВЕ ЗАБЕЗПЕЧЕННЯ ДОКУМЕНТАЛЬНОГО КОНТРОЛЮ ЗА ОБІГОМ ЗБРОЇ ТА ВИБУХОВИХ МАТЕРІАЛІВ В УКРАЇНІ
}

У статті розглянуто особливості документального обліку руху зброї та вибухових матеріалів у суспільстві, акцентовано увагу на значенні облікових та інших документів, що $є$ носіями інформації про поводження зі зброєю та вибуховими матеріалами різними суб'єктами, для організації контролю та розслідування правопорушень у цій сфері. Запропоновано класифікацію документів, які дають уявлення про суб'єктів поводження зі зброєю, рух зброї та вибухових матеріалів, їх використання (застосування).

Ключові слова: документальний облік руху зброї та вибухових матеріалів, контроль за використанням (застосуванням) зброї та вибухових матеріалів, поводження зі зброєю та вибуховими матеріалами.

Постановка проблеми. Суспільна небезпечність незаконного поводження зі зброєю та вибуховими матеріалами полягає в тому, що воно сприяє вчиненню злочинів із використанням зазначених предметів. Тому законодавством 
встановлено вимоги, правила, спрямовані на: взяття під контроль виробництва зброї та вибухових речовин, а також осіб, які таке виробництво організують; запровадження всеохоплювального обліку руху зброї та вибухових речовин у суспільстві тощо. Таке значення для суспільства цього питання та увага на нормативно-правовому рівні щодо забезпечення безпечного обігу зброї та вибухових матеріалів зумовило значний інтерес до досліджень проблем, пов'язаних із запобіганням незаконному обігу зазначених об'єктів, зокрема за допомогою заходів контролю, облікових та інших заходів.

Аналіз останніх досліджень і публікацій. Питанню запобігання нелегальному обігу зброї та злочинів, пов'язаних із застосуванням зброї та вибухових речовин, присвячені численні дослідження, у контексті яких розглядаються й питання документального контролю в цій сфері. Це, зокрема, праці Я. Ю. Бандуріної, $\quad$ В.С. Бондаря, Н. В. Деркач, О. В. Кириченка, Ю. Ф. Кравченка, М. В. Кривоноса, М. М. Майстренка, П. М. Мітрухова, В. П. Меживого, А. С. Новосада, М. Г. Пінчука, В. В. Поливоди, О. М. Сарнавського, М. В. Стащака, В. В. Шендрика та інших. Для цієї сфери важливе значення мають i дослідження (зокрема А. П. Слободзяна, M. І. Фіалка та інших), у яких розглядаються загальні питання роботи 3 документами (статистичними обліками, матеріалами органів контролю тощо) як джерелами кримінологічної інформації.

Формування цілей. Автор має на меті дослідити особливості документального обліку руху зброї та вибухових матеріалів у суспільстві, склад документів, що є носіями інформації про поводження зі зброєю й вибуховими матеріалами, та використання їх (документів) для отримання інформації про правопорушення в цій сфері.

Виклад основного матеріалу. Особливістю законодавства про обіг зброї та вибухових матеріалів є те, що передбачена ним система контролю за таким обігом є постійно діючою, дає змогу в будь-який момент перевіряти та переперевіряти інформацію про додержання правових вимог у цій сфері, повертатися до цієї інформації, якщо цього вимагають потреби контролю чи розслідування відповідних правопорушень. Це досягається насамперед за допомогою приписів, які передбачають документальне оформлення чи фіксацію будь-яких дій та заходів з поводження зі зброєю та вибуховими матеріалами. Такий підхід само собою дисциплінує учасників відносин 3 поводження $з$ цього роду предметами, але при цьому утворює постійно діючу інформаційну базу про об'єкти, де можуть виникати проблеми із забезпечення законного обігу зброї та вибухових матеріалів, і де ці проблеми мають вирішуватися.

Відповідне документування починає здійснюватися зі стадії оформлення ліцензій та дозволів на поводження зі зброєю та вибуховими матеріалами. Ця стадія задає тон усьому наступному процесу забезпечення безпеки поводження зі зброєю та вибуховими матеріалами, призначена звести до мінімуму можливість допуску до виробництва, торгівлі, зберігання, користування та іншого поводження з ними «випадкових» осіб, професійно непідготовлених, які не мають належної матеріально-технічної бази для 
зберігання, охорони відповідних предметів тощо. Згідно з ліцензійними умовами та умовами надання дозволів, визначених спеціальними нормативно-правовими актами [1], оцінка відповідних осіб здійснюється за допомогою комплексу документів, котрі вони мають подати до ліцензійних органів та органів дозвільної системи для отримання ліцензій чи дозволів на здійснення діяльності, пов'язаної з поводженням зі зброєю та вибуховими матеріалами (щодо отримання ліцензій: до МВС - 3 питань виробництва, ремонту, торгівлі зброєю та Держпраці - 3 питань виробництва вибухових матеріалів промислового призначення; щодо отримання дозволів - до органів дозвільної системи МВС 3 питань виготовлення, придбання, зберігання, перевезення та використання зброї, а також з питань придбання, зберігання та перевезення вибухових матеріалів, та Держпраці - 3 питань проведення вибухових робіт та виготовлення засобів їх механізації). Ідеться про документи, що мають засвідчити особу, яка бажає отримати ліцензію чи дозвіл (копія паспорта); підтвердити наявність у здобувача ліцензії (дозволу) та найманих працівників необхідної освіти та проходження спеціальної підготовки (копії дипломів, свідоцтв), відсутність у них медичних протипоказань до виконання ними функціональних обов' язків та володіння зброєю, спеціальними засобами, а також право власності на відповідне майно чи право оренди приміщень для провадження відповідного виду господарської діяльності (копії документів, що це право підтверджують) тощо. Усі документи 3 питань ліцензування та отримання дозволів зберігаються в установленому порядку в ліцензійних органах та органах дозвільної системи.

Основними документами, що фіксують право особи на поводження зі зброєю й вибуховими матеріалами та породжують у них обов'язок виконувати організаційні, кадрові та технологічні вимоги, визначені відповідними нормативно-правовими актами, є ліцензії та дозволи.

Ліцензія - це запис у Сдиному державному реєстрі юридичних осіб, фізичних осіб - підприємців та громадських формувань про рішення органу ліцензування щодо наявності в суб'єкта господарювання права на провадження визначеного ним виду господарської діяльності, що підлягає ліцензуванню (пункт 5 ст. 1 Закону України «Про ліцензування видів господарської діяльності»). У цьому Реєстрі також зберігаються електронні копії документів, що подавалися відповідною особою до органу ліцензування. Електронні копії документів є також невід'ємною частиною ліцензійної справи (це єдиний набір документів на паперових або електронних носіях стосовно відповідного здобувача ліцензії, які подані ним, надходять до органу ліцензування від органів державної влади, юридичних або фізичних осіб чи прийняті органом ліцензування в результаті реалізації своїх повноважень), які формують і зберігають органи ліцензування (ст. 17 Закону України «Про ліцензування видів господарської діяльності»).

Дозвіл - це документ, який орган дозвільної системи зобов'язаний видати певному суб'єктові в разі надання йому права на провадження певних дій зі зброєю та вибуховими матеріалами. На об'єкти, на які 
поширюється дозвільна система, заводяться облікові справи, а на власників зброї - особові справи, у яких містяться матеріали (документи), пов'язані $з$ наданням відповідних дозволів.

Важливу групу документів складають ті, що забезпечують додержання режиму охорони та збереження зброї, вибухових матеріалів, пропускного режиму на територію, де вони містяться. Це, зокрема, наказ керівника суб'єкта господарювання про призначення особи, відповідальної за облік вибухових матеріалів; розпорядчий документ про призначення посадової особи, відповідальної за охорону небезпечної зони при проведені вибухових робіт; положення про керівництво роботами, пов'язаними 3 обігом вибухових матеріалів, затверджене суб'єктом господарювання; інструкція щодо пропускного і внутрішнього об'єктового режиму з урахуванням особливостей об'єкта, який охороняється, режиму робочого часу, постійних і тимчасових перепусток, порядку входу й виходу громадян, внесення i винесення (вивезення) зброї, боєприпасів до неї, спеціальних засобів, яку повинен мати відповідний суб'єкт господарювання тощо. У разі виявлення правопорушення в цій сфері документи вказаної групи допомагають з'ясувати обстановку його вчинення, пов'язану з місцем цієї події, умовами зберігання й охорони предметів озброєння та вибухових матеріалів.

Ключова роль у забезпеченні контролю за рухом зброї, бойових припасів до неї, пристроїв, патронів до них, вибухових матеріалів і речовин, переходу їх від одних осіб до інших, використанням їх у службових та виробничих цілях належить обліковим документам. Завдяки їм виявляються місця несанкціонованого вилучення зброї, вибухових матеріалів, звідки вони поступають у нелегальний обіг, особи, які причіпні (або ж можуть бути причетні) до цього, установлюється час, коли це відбулося тощо. Тому органи, що здійснюють контроль у цій сфері, а також ті, які забезпечують розслідування правопорушень, пов'язаних зі зброєю та вибуховими матеріалами, мають орієнтуватися в складі відповідних облікових документів. Він визначається відповідними нормативно-правовими актами.

Зокрема, Ліцензійними умовами провадження господарської діяльності з виробництва та ремонту вогнепальної зброї (...), затверджених постановою Кабінету Міністрів України від 02.12.2015 № 1000 [2], передбачено ведення книг обліку: виготовленої зброї, боєприпасів до неї, спеціальних засобів (додатки 4-6); зброї, що надійшла для ремонту (додаток 7); зброї (додаток 9), боєприпасів до неї (додаток 10), спеціальних засобів (додаток 11), торгівлю якими провадить відповідний суб'єкт господарювання. Обліковий характер має направлення, згідно з яким зброя та спеціальні засоби здаються для комісійного продажу громадянами або представниками юридичної особи (додаток 8). У зазначених документах містяться основні характеристики зброї, іiі комплектуючих, наводиться інформація про постачальників комплектуючих зброї, осіб, яким виготовлена зброя передана чи реалізована. Приміром, у Книзі обліку зброї, яку веде суб'єкт господарювання, що провадить діяльність з торгівлі зброєю, має фіксуватися інформація про ії надходження (зазначатися: найменування суб'єкта господарювання, від якого надійшла зброя, його місцезнаходження; прізвище, ім'я, по батькові 
власника, місце проживання; номер дозволу на придбання (ким і коли виданий), накладної, направлення; марка (модель), калібр, серія, номер зброї) та реалізацію (найменування суб'єкта господарювання, якому реалізовано зброю, його місцезнаходження; прізвище, ім'я, по батькові особи, якій реалізовано зброю, місце проживання, серія, номер паспорта (ким і коли виданий); номер дозволу на придбання (ким і коли виданий).

Велика група облікових документів передбачена Інструкцією про порядок виготовлення, придбання, зберігання, обліку, перевезення та використання вогнепальної, пневматичної, холодної й охолощеної зброї (...), а також боєприпасів до зброї та вибухових матеріалів, затвердженої наказом Міністерства внутрішніх справ України від 21.08.1998 № 622 [3]. Це, зокрема, книга обліку об'єктів дозвільної системи, які перебувають під контролем (підпункт 6.1. пункту 6). До таких об'єктів належать: сховища, склади, де зберігаються вибухові матеріали иे речовини, піротехнічні майстерні, стрілецькі тири й стрільбища, мисливсько-спортивні стенди, а також підприємства й майстерні з виготовлення й ремонту вогнепальної, холодної та охолощеної зброї, спеціальних засобів, заряджених речовинами сльозоточивої та дратівної дії, індивідуального захисту, активної оборони, магазини, у яких здійснюється продаж зброї та бойових припасів до неї, основних частин зброї, пристроїв та патронів до них. На кожний об'єкт дозвільної системи заводиться облікова справа, якій присвоюється реєстраційний номер. Облік власників мисливської вогнепальної нарізної, гладкоствольної, пневматичної, а також холодної зброї, пристроїв здійснюється в книзі обліку власників мисливської вогнепальної, пневматичної зброї, а також холодної зброї. Відомості про наявність такої зброї в громадян заносяться до Інтегрованої інформаційно-пошукової системи органів внутрішніх справ (IIПС ОВС) (підпункт 7.1. пункту 7 Ліцензійних умов провадження господарської діяльності з виробництва та ремонту вогнепальної зброї невійськового призначення й боєприпасів до неї ...). А юридичні особи, які використовують зброю й бойові припаси до неї, пристрої та зазначені патрони, мають вести книги обліку вогнепальної зброї й бойових припасів на підприємствах, в установах, організаціях, що мають бути пронумеровані, прошнуровані й скріплені печаткою органу внутрішніх справ (підпункт 11.20. пункту 11 Інструкції МВС від 21.08.1998 № 622). Ведення облікових документів та вирішення інших питань щодо зброї згідно із зазначеною Інструкцією від 21.08.1998 № 622 передбачається інструкціями, узгодженими з МВС України, про порядок придбання, зберігання, обліку, охорони, перевезення й використання зброї та бойових припасів до неї в міністерствах, інших центральних органах влади, на підприємствах, в установах, організаціях і господарських об'єднаннях.

У фіксації обігу зброї важливу роль відіграє інтегрована інформаційнопошукова система органів внутрішніх справ України (IIПС), Положення про яку затверджено наказом МВС від 12.10.2009 № 436 [4]. Метою створення ІІПС $є$ об'єднання наявних в органах та підрозділах внутрішніх справ України інформаційних ресурсів у єдиний інформаційно-аналітичний комплекс із використанням сучасних інформаційних технологій, комп'ютерного та 
телекомунікаційного обладнання для підтримки оперативно-службової діяльності органів і підрозділів внутрішніх справ, суттевого зміцнення їх спроможності протидії та профілактики злочинності. До складу інформаційних ресурсів ІІПС належать, серед інших, відомості, що стосуються: зброї, яка перебуває в користуванні громадян, підприємств, установ, організацій, господарських об'єднань, яким надано відповідно до законодавства дозвіл на ii придбання, зберігання, носіння, перевезення, та яка обліковується підрозділами дозвільної системи; викраденої, втраченої, вилученої, знайденої зброї, а також добровільно зданої із числа тієї, що незаконно зберігалася.

Інструкцією про порядок виготовлення, придбання, зберігання, обліку, перевезення та використання вогнепальної, пневматичної, холодної й охолощеної зброї (...), а також боєприпасів до зброї та вибухових матеріалів, затвердженої наказом МВС України 21.08.1998 № 622, передбачено також ведення облікових документів щодо вибухових матеріалів. Зокрема, на відповідні підприємства покладено обов'язок вести облік надходжень i витрат вибухових матеріалів на складах ВМ у книзі обліку надходжень i витрат вибухових матеріалів, а на складах і в роздавальних камерах, 3 яких відбувається видавання вибухових матеріалів підривникам і приймання від них решток ВM, - у книзі видачі й повернення вибухових матеріалів. Книги, які ведуть завідувачі складів і роздавальники, мають бути пронумеровані, прошнуровані й скріплені печаткою або пломбою органу Держгірпромнагляду України (підпункт 16.1. пункту 16 Інструкції). Фіксацію руху вибухових матеріалів здійснюють також за прибутково-видатковими документами. Зокрема, вибухові матеріали оприбутковують за відправними заводськими (транспортними) документами або нарядом-накладною (виписує бухгалтерія підприємства (шахти, рудника, кар'єру тощо), у віданні якого перебуває склад, служить для відпуску потрібних матеріалів з одного місця зберігання до іншого) чи нарядом путівкою (призначена для відпускання вибухових матеріалів підривникам (майстрам-підривника), підписує начальник дільниці (цеху), на якій проводять підривні роботи, або його заступник (прораб, старший майстер тощо) (підпункти 16.4., 16.5., 16.6. пункту 6 Інструкції).

Відповідні книги обліку вибухових матеріалів, порядок їх ведення, а також особливості обліку вибухових матеріалів під час проведення вибухових робіт, при їх випробуванні та знищенні передбачені також Порядком обліку вибухових матеріалів промислового призначення, затвердженого наказом МНС України від 06.07.2006 № 424 [5] та іншими нормативно-правовими актами (зокрема, Порядком знищення вибухових матеріалів промислового призначення, затвердженого наказом МНС України від 06.07.2006 № 423; Порядком реалізації надлишку вибухових матеріалів промислового призначення або таких, потреба у яких відпала, затвердженого наказом МНС України від 29.03.2006 № 179; Правилами безпеки під час поводження з вибуховими матеріалами промислового призначення, затверджені наказом Міністерства енергетики та вугільної промисловості України від 12.06.2013). 
У системі обліку зброї та вибухових матеріалів важлива роль належить ïx маркуванню. Останнє дає змогу в будь-яких випадках, зокрема в разі скоєння 3 використанням зброї та вибухових матеріалів злочинів, ідентифікувати ці предмети, та визначити місце, звідки вони були незаконно вилучені. Відповідними нормативно-правовими актами встановлено, що вся виготовлена зброя, спеціальні засоби мають мати номер і штамп (марку) виробника. Нумерація виготовленої зброї, спеціальних засобів має здійснюватися за погодженням 3 МВС відповідно до індексів, що встановлюються для м. Києва та областей. Номери для кожного регіону починаються 3 цифр 000001 (пункт 10 Ліцензійних умов провадження господарської діяльності з виробництва та ремонту вогнепальної зброї невійськового призначення й боєприпасів до неї ... [2]). Для вибухових матеріалів передбачено, що всі вони мають бути промарковані в умовах виробника, підприємства-споживача та містити особисту позначку майстрапідривника під час їх видавання останнім зі складу ВМ для проведення вибухових робіт (підпункт 13.2. пункту 13 Інструкції про порядок виготовлення, придбання, зберігання, обліку, перевезення та використання вогнепальної, пневматичної, холодної й охолощеної зброї ... [3].

Про стан здійснення заходів із забезпечення режиму безпеки на об'єктах, де виробляються та зберігається зброя й вибухові матеріали можна дізнатися з так званої організаційно-розпорядчої документації (накази, розпорядження, акти, інструкції, положення тощо), якою призначаються на посади особи, відповідальні за ту чи іншу ділянку поводження зі зброєю та вибуховими матеріалами; визначається порядок здійснення відповідними особами функцій з обліку зброї чи вибухових матеріалів; встановлюється порядок дії пропускного режиму на відповідних об'єктах, включаючи внесення й винесення (вивезення) зброї, боєприпасів до неї, спеціальних засобів, яку має мати відповідний суб'єкт господарювання; організується проведення перевірки стану збереження зброї та вибухових матеріалів; затверджується порядок оформлення перепусток на територію, де зберігаються вибухові матеріали; затверджується проектно-технічна документація на проведення вибухових робіт; регламентується керівництво підривними роботами тощо.

У складі документації з питань поводження зі зброєю та вибуховими матеріалами варто також виділити ті, що фіксують різного роду порушення вимог законодавства з питань їх охорони, цільового використання. Ідеться про документи, що оформлюються за результатами перевірок суб'єктів сфери поводження зі зброєю та вибуховими матеріалами. Такі перевірки здійснюють органи ліцензування та органи дозвільної системи стосовно осіб, суб'єктів господарювання та суб'єктів певної сфери управління, які отримали ліцензії чи дозволи на поводження зі зброєю та вибуховими матеріалами, на предмет додержання ними ліцензійних умов та умов надання відповідних дозволів. Також перевірку стану обліку, збереження зброї та вибухових матеріалів здійснюють особи, визначені відповідними відомчими інструкціями, уповноважені на це наказами керівників підприємств, де є зброя, командирами військових частин. За загальним 
правилом результати перевірки оформляються актом чи рапортом (у Збройних силах України результати перевірок заносяться до книги огляду (перевірки) озброєння, техніки та боєприпасів). У них фіксуються виявлені порушення, передбачаються заходи щодо їх усунення. Така інформація надалі може бути корисною при пошуку каналів надходження в незаконний обіг зброї та вибухових матеріалів.

Отже, документація, що фіксує всі моменти поводження зі зброєю та вибуховими матеріалами, події навколо цього поводження, відіграє важливу роль у розслідуванні правопорушень у цій сфері. Для ліпшої орієнтації у складі цієї документації в ній можна виділити окремі групи документів, ураховуючи їх призначення та застосування. За цим критерієм їх можна поділити на документи: а) персонального; б) організаційно-розпорядчого; в) облікового; г) господарського та технічного характеру; г) 3 питань контролю та реагування на правопорушення в цій сфері. Ці документи відповідно до законів та інших нормативно-правових актів додаються до заяв на отримання відповідних ліцензій та дозволів, породжують у суб'єктів поводження зі зброєю та вибуховими матеріалами певні права та обов'язки, фіксують рух зброї та вибухових матеріалів.

Зокрема, належать до документів:

а) персонального характеру - копії документів, що підтверджують наявність у працівників відповідної освіти та кваліфікації (диплом, свідоцтво), необхідних для провадження господарської діяльності 3 виробництва вибухових матеріалів; копія документа, що підтверджує відсутність у керівника здобувача ліцензії та найманих працівників медичних протипоказань до виконання ними функціональних обов' язків та володіння зброєю, спеціальними засобами, який видається в установленому порядку (зберігаються в ліцензійних справах та в облікових справах, що ведуть органи дозвільної системи) тощо;

б) організаційно-розпорядчого характеру - копія дозволу на відкриття об'єкта дозвільної системи; наказ керівника суб'єкта господарювання про призначення особи, відповідальної за облік вибухових матеріалів; наказ командира військової частини про призначення особи, яка відповідає за облік, зберігання ѝ видачу стрілецької зброї та боєприпасів; затверджене суб'єктом господарювання Положення про керівництво підривними роботами; свідоцтво на придбання вибухових матеріалів, що видається територіальним органом Держгірпромнагляду України; розпорядчий документ про призначення посадової особи, відповідальної за охорону небезпечної зони при проведенні вибухових робіт; положення про керівництво роботами, пов'язаними 3 обігом вибухових матеріалів, затверджене суб'єктом господарювання; інструкція щодо пропускного і внутрішнього об'єктового режиму з урахуванням особливостей об' єкта, який охороняється, режиму робочого часу, постійних і тимчасових перепусток, порядку входу й виходу громадян, внесення і винесення (вивезення) зброї, боєприпасів до неї, спеціальних засобів, яку має мати відповідний суб'єкт господарювання тощо;

в) облікового характеру - книги обліку виготовленої зброї, боєприпасів до неї, спеціальних засобів; книги обліку зброї, що надійшла для ремонту; 
книга обліку зброї, яку веде суб'єкт господарювання, що провадить діяльність 3 торгівлі зброєю; книги обліку надходжень та витрат вибухових матеріалів; акти приймання, придбаної зброї та боєприпасів; накладні про передачу придбаної зброї та боєприпасів; акти списання бойових припасів; роздавально-здавальна відомість боєприпасів на пункті бойового постачання військової частини; книги обліку видачі та повернення вибухових матеріалів; наряди-путівки на проведення вибухових робіт; книги обліку видачі та повернення вибухових матеріалів; книги обліку видачі та приймання вогнепальної зброї й боєприпасів; книги обліку озброєння та техніки за номерами й технічним станом; книга обліку об'єктів дозвільної системи, які перебувають під контролем; книга обліку власників мисливської вогнепальної, пневматичної зброї, а також холодної зброї тощо;

г) господарського та технічного характеру - копія документів (свідоцтво про право власності, договір оренди, договір концесії, договір управління і спільної діяльності), що підтверджують право власності або користування площами (приміщеннями) для провадження відповідного виду господарської діяльності; копії документів, що є підставою для придбання зброї невійськового призначення та бойових припасів до неї (договір купівліпродажу, контракт тощо); наряди-накладні на видачу вибухових матеріалів; наряди-накладні, за якими здійснюється перевезення вибухових матеріалів; нормативні документи у сфері стандартизації (стандарти, технічні регламенти, технічні умови) на кожен вид продукції, що буде вироблятися (зброя, боєприпаси до неї, спеціальні засоби); копія паспорта складу вибухових матеріалів; копії технологічних регламентів виробництва вибухових матеріалів; паспорти (формуляри) обладнання тощо).

г) 3 питань контролю та реагування на правопорушення у цій сфері акти, рапорти, складені за результатами проведення планових (позапланових) заходів державного нагляду (контролю); акти про вилучення зброї та боєприпасів; накази керівника суб'єкта господарювання про проведення перевірки стану збереження зброї та вибухових матеріалів; доповіді й донесення про події, кримінальні правопорушення, адміністративні правопорушення, пов'язані зі зброєю та боєприпасами, облік яких здійснюється в Міністерстві оборони України та Збройних силах України; документація про випадки порушень режиму та маршруту руху, зокрема затримання транспортних засобів зі зброєю, боєприпасами або вибуховими матеріалами тощо.

Висновки. Законодавство, яке аналізуємо, є результатом трансформації правові норми досвіду практики поводження зі зброєю в суспільстві, застосування вибухових речовин у виробництві, боротьби зі злочинністю, пов'язаної з їх (зброї, вибухових матеріалів) використанням. Цей досвід відбився в широкому діапазоні дії відповідних правових норм, яка охопила всі проблемні зони (об'єкти) поводження зі зброєю, вибуховими матеріалами. Вони (правові норми) передбачають документальне оформлення чи фіксацію будь-яких дій та заходів з поводження зі зброєю та вибуховими матеріалами. У цьому задіяні різноманітні групи документів, що дають уявлення про суб'єктів поводження зі зброєю, рух 
зброї та вибухових матеріалів, їх використання (застосування) тощо. Інформація, що міститься в цих документах, відіграє важливу роль у встановленні каналів надходження в незаконний обіг зброї та вибухових матеріалів, виявленні правопорушників у цій сфері суспільних відносин.

\section{Використані джерела:}

1. Про ліцензування видів господарської діяльності: Закон України від 02.03.2015 № 222-VIII. URL: https://zakon.rada.gov.ua/laws/show/222-19; Положення про дозвільну систему: Постанова Кабінету Міністрів України від 12.10.1992 № 576. URL: https:// zakon.rada.gov.ua/laws/show/576-92-\%D0\%BF.

2. Ліцензійні умови провадження господарської діяльності з виробництва вибухових матеріалів промислового призначення: Постанова Кабінету Міністрів України від 22.07.2016 № 604. URL: https://zakon.rada.gov.ua/laws/show/6042016-\%D0\%BF та інші нормативно-правові акти.

3. Ліцензійні умови провадження господарської діяльності з виробництва та ремонту вогнепальної зброї невійськового призначення й боєприпасів до неї, холодної зброї, пневматичної зброї калібру понад 4,5 міліметра і швидкістю польоту кулі понад 100 метрів на секунду, торгівлі вогнепальною зброєю невійськового призначення та боєприпасами до неї, холодною зброєю, пневматичною зброєю калібру понад 4,5 міліметра і швидкістю польоту кулі понад 100 метрів на секунду; виробництва спеціальних засобів, заряджених речовинами сльозоточивої та дратівної дії, індивідуального захисту, активної оборони та їх продажу: Постанова Кабінету Міністрів України від 02.12.2015 № 1000. URL: https:/ / zakon.rada.gov.ua/laws/show/1000-2015-\%D0\%BF.

4. Інструкція про порядок виготовлення, придбання, зберігання, обліку, перевезення та використання вогнепальної, пневматичної, холодної й охолощеної зброї, пристроїв вітчизняного виробництва для відстрілу патронів, споряджених гумовими чи аналогічними за своїми властивостями метальними снарядами несмертельної дії, та патронів до них, а також боєприпасів до зброї, основних частин зброї та вибухових матеріалів: Наказ Міністерства внутрішніх справ України від 21.08.1998 №622. URL: https:/ / zakon.rada.gov.ua/laws/ show/z0637-98.

5. Положення про Інтегровану інформаційно-пошукову систему органів внутрішніх справ України: Наказ МВС України від 12.10.2009 № 436. URL: https://zakon.rada.gov.ua/laws/show/z1256-09.

6. Порядок обліку вибухових матеріалів промислового призначення: Наказ MHC України від 06.07.2006 № 424. URL: https:/ / zakon.rada.gov.ua/laws/show.

Стаття надійшла до редколегіï 03.03.2019

Ерофеев Н. И., кандидат юридических наук, научный сотрудник научноисследовательской лаборатории по проблемам предупреждения, прекращения и расследования преступлений территориальными органами Национальной полиции Украины Луганского государственного университета внутренних дел имени Э. А. Дидоренко (г. Северодонецк, Украина)

Правовое обеспечение документального контроля за обращением оружия и взрывчатых материалов в Украине

В статье рассмотрены особенности документального учета движения оружия и взрывчатых материалов в обществе, акцентировано внимание на значении учетных 
документов и других документов, которые являются носителями информации об обращении с оружием и взрывчатыми материалами разными субъектами, для организации контроля и расследования правонарушений в данной сфере. Предложена квалификация документов, которые дают представление о субъектах обращения с оружием, движения оружия и взрывчатых материалов, их использования (применения).

Ключевые слова: документальный учет движения оружия и взрывчатых материалов, контроль за использованием (применением) оружия и взрывчатых материалов, обращение с оружием и взрывчатыми материалами.

\section{Ierofeiev M. Legal Providing of Documentary Control to Monitor the Movement of Weapons and Explosives in Ukraine}

The article deals with the peculiarities of documentary accounting of the movement of weapons and explosives in society, emphasizes the importance of accounting and other documents that bear the information on the handling of weapons and explosive materials by various entities for the organization of control and investigation of offenses in this area.

In particular, it is noted that the system of documentary control over the circulation of weapons and explosive materials is permanent, allows at any time to check and re-check information on compliance with legal requirements in this area, to return to this information if this is required by the requirements of control or investigation of the relevant offenses This is achieved primarily by means of legislative provisions that provide for the documenting or fixing of any actions and measures for the handling of weapons and explosives. Such an approach, as emphasized in the article, disciplines itself on the part of the participants in the relations with the handling of objects of this kind, but at the same time forms a permanent information base on objects where problems may arise in ensuring the lawful circulation of weapons and explosive materials, and where these problems have to be solved.

Also, the composition of the documentation that controls the circulation of weapons and explosives is considered, and the classification of documents included in its (documentation) composition is proposed. In particular, the following groups of relevant documents are allocated: a) personal character (copies of documents confirming the presence of employees with appropriate education and qualifications); b) organizational and administrative nature (documents that ensure the introduction of weapons and explosives in the relevant facility, their production and other treatment, the special security regime and the persons responsible for organizing this regime; c) the accounting nature (documents recording the movement of weapons and explosives); d) economic and technical character (documents confirming the person's right to engage in activities related to the production, sale and other handling of weapons and explosives); e) on issues of control and response to offenses in this area (documents, which record the results of control measures on the relevant issue, the facts of the seizure of weapons and ammunition, and established violations in this area).

Key words: documentary accounting of the movement of weapons and explosives, control over the use (use) of weapons and explosives, handling weapons and explosives. 